\title{
The Information Environment of Distance Learners: A Literature Review
}

\author{
Olugbade Oladokun \\ Department of Library and Information Studies, University of Botswana, Gaborone, Botswana \\ Email: OLADOKUN@mopipi.ub.bw
}

Received 24 February 2014; revised 24 March 2014; accepted 1 April 2014

Copyright (C) 2014 by author and Scientific Research Publishing Inc. This work is licensed under the Creative Commons Attribution International License (CC BY). http://creativecommons.org/licenses/by/4.0/

\section{Abstract}

The distance mode of educational delivery has become a very trendy method of popularizing education and breaking down the "insularity and the elitism of the typical conventional university". It is widely known that distance learners can be found everywhere and anywhere-in metropolitan, non-metropolitan areas as well as any other environment. It is equally known that the information environment of users should aim to allow discovery, access and use of resources for research and learning irrespective of a user's location. Consequent upon the fact that information support services are part of higher education programmes that add to the value and quality of learning regardless of the mode of delivery, the information needs of distance learners deserve to be met, irrespective of where they are located. It is in this respect that this review of literature seeks to examine the information needs of distance learners. It also peeps into the information (seeking) behaviour culminating in how the information needs of distance learners are met. The other aspect of this review is the channels and, or sources of information through which the information needs of distance (remote) learners are met. Some of the sources or channels considered are the library, modules/study guides, lecturers or tutors, interaction with peers, friends/colleagues and massmedia. The review examines literature both in the western world, as well as what is available in Africa.

\section{Keywords}

Distance Learners; Information Environment; Mass-Media; Information Sources/Channels; Information Needs; Information (Seeking) Behaviour

\section{Introduction}

The intent of this paper is to present a review of literature significant to information environment of distance 
learners. Under the umbrella of information environment, this literature review covers information needs as well as the information (seeking) behaviour culminating in how the information needs of distance learners are met. This review is not looking at the basic character and nature of distance education. The channels and, or sources of information through which the information needs of distance (remote) learners are met will also be given consideration in the course of carrying out this review of literature. These information channels or sources, among others, include the Internet, electronic databases and dial-in access to computer catalogues, remote or modem access to CD-ROM, emailing system, facsimile and telephone. These are embedded in the review. Other information sources/channels include library, modules/study guides, bookstores, lecturers or tutors, handouts, interaction with peers, friends/colleagues and mass-media such as radio and television.

\section{Distance Learners: Information Environment and Information Needs}

Information environment is viewed as the type of environment which individuals interact with either for purposes of providing or obtaining information for use in day-to-day living or to perform a task. In this context, distance learning is viewed as the task. Information environment can also refer to the context in which information is sourced, accessed, managed, utilised and generally made available for the use of distance learners in pursuit of their distance learning programmes. The sources and/or channels of information comprise colleagues or friends, mass-media such as radio and television and newspapers, library and electronic mediated devices such as the Internet, among others.

Some attempts have been made to explain or substantiate on the information needs of distance learners. From her point of view, Jagannathan (1998: p. 140) categorised distance students information requirements as:

Need for materials and facilities: Distance learners need several kinds of materials such as reference books, texts books, journals, reports, Self-Instructional Materials (SIMs) etc. They require various facilities, viz. library reading room as well as stack room space with proper display of documents.

Need for information services: such as bibliographic instruction for print and non-print materials; information about distance learning agencies, and support services.

Need for user services: Distance learners also need professional guidance and support from the library staff about using library collection, using equipment and facilities available at the library. (Jagannathan, 1998: p. 140)

In their submission, Kascus and Aguilar (1988) said the following requirements constitute the basic information needs of distance learners: access to adequate facilities; core collections; professional library staff; reserve reading collections; and supplementary materials. Singh (2002) also argues that distance learners generally need some of the following types of... information services, namely the loan of a specific book/reference book usually one referred to in their SIMs; a photocopy of a specific journal article or single chapter of a book; a photocopy of previous examination papers for their course; information/material on a particular subject; self instructional materials; viewing and listening to audio-visual materials; using the different type of library collection; and using equipment and facilities available.

In a document that details establishing and managing distance librarianship, the Commonwealth of Learning (COL, 2003) notes that the basic information services distance learners need are access to information resources, such as texts, supplementary reading and reference services; learning how to find the information they need from the information that is available and developing ways to apply the information gleaned and to make sound, information-based decisions.

\section{Distance Learners: Information Seeking Behaviour}

It has been mentioned that information seeking behaviour also constitutes one of the components of the information environment of distance learners. As noted, information seeking behaviour is the manner individuals articulate their information needs, search, recognize, retrieve and use information. It is the mode an individual goes about to search for the information he needs to perform a task at hand or meet his needs. In an exposition, Sharifabadi (1992) cited a survey conducted at the University of Wyoming (UW) in 1983 on off-campus students. The result showed that a large proportion of UW-Casper and extension (off-campus) respondents tended to use 
public libraries rather than academic libraries because they were more familiar with or more convenient to obtain their information needs. Sharifabadi (1992) also provides an account of a survey carried out at the Deakin University in Australia in 1987. The institution operates distance education programme. According to Sharifabadi, the findings of the survey showed that in terms of information usage or sources used, personal collection was the first option for external students. However, a majority of external students were frequent users of public libraries, using public libraries more frequently than any other type of library, including the student's own university library. The result also indicated that the lower the level of course, the greater the usage by external students of public libraries, and the higher the level, the greater the usage of academic libraries.

In a survey by Sutherland (2000) on information use among distance learners associated with Western Colorado Graduate Center in the US, she found that majority of the survey participants borrowed materials from local academic and local public libraries. The result also revealed that more than half of the students did not use the main campus (distance education provider) library. Response by 71 students revealed that $37 \%$ borrowed materials from distance education provider libraries, $69 \%$ used the local academic library, $73 \%$ used the local public library and $20 \%$ used other resources, such as a library consortia, professional library, or personal material and online resources. Reasons given for using what they used include: ease of use, location and resources, among others. In a study on distance learners at the University of Maryland University College (UMUC), Kelley and Orr (2003) observe that the findings of their survey confirm some other studies and observations suggesting that students prefer using online resources to physical library buildings and collections. In exploring some research questions about library and web usage, Kelley and Orr found that students ranked full-text library databases and off-campus access to the library catalog as the most useful library services provided. Respondents also indicated a preference for web-based delivery of library instruction over other methods of instruction, and found web-based information about library services more useful than other formats.

Similarly, Moyo and Ellysa (2003) did another survey to discover the attitudes of distance learners on the quality and use of available information resources and services at Penn State World Campus. The survey results indicate, among other things, that students are interested in access to more online full-text resources along with speedy document delivery for materials not online full-text. In a related exercise at Texas A \& M University (TAMU), USA, Liu and Zheng (2004) conducted a survey on factors influencing distance education graduate students' use of information sources. They found that graduate distance education students preferred information sources that are fast and easy to use. Internet and electronic library resources were therefore preferred to traditional library resources by most respondents. In a survey of the University of Iowa distance education students conducted by McLean and Dew (2004), the students were asked to reflect and rate a number of information resources and services used. Over seventy percent graded the distance education library services Website as "good" or "excellent"; over eighty percent graded the student handouts summarizing distance education library services as "good or "excellent". Eighty seven percent rated toll free telephone reference services as "good" or "excellent", seventy-seven percent rated the e-mail reference service as "good" or "excellent" and over ninety percent rated the document delivery service as "good" or "excellent. In observing the ranking of library services that students value most, McLean and Dew note that access to electronic resources ranked the highest, followed by access to document delivery, followed by access to reference help, followed finally by instruction. Regarding the Internet connections, it was observed that the vast majority of students had Internet access from home (over ninety percent), about half had access from their offices and over forty percent used the access provided at their local public library. About sixty percent had access through a telephone modem, twenty-five percent had access through cable, and less than twenty percent had T-1 access to the Internet. McLean and Dew (2004) in another related study on distance learners at the University of West Indies (UWI) — an institution in a developing country, wanted, among others, to determine the distance students use of and satisfaction with available services and also determine their new service requirement. The results show that fifty-three percent of the sample said they had access to the Internet. Home (36.6\%), work (25.4\%) and UWI sites (20.6\%) were the chief access points. It is noted that access to the three primary electronic resources (the Mona catalogue, databases and electronic journals) received approximately the same rating (extremely useful to useful).

In a treatise at the UK Open University (OU), Bremner (2000) examines the students' projects. The first findings of the survey carried out in 1999 involving 1500 students from all courses showed the pattern that far more students were using resources not provided by OU course materials than had been expected. Three fifths of both undergraduates and postgraduates were using other information gathered from various sources including bookshops, public and academic libraries, the Internet, television, and newspapers and magazines they bought them- 
selves. When asked about the type of information they had used OU students indicated that books were the items most frequently used, followed by newspaper articles, encyclopaedias, Internet (Web) sites and journal articles. Internet sites were being consulted far more frequently than traditional sources of academic research material, such as journal articles, which raises issues regarding the quality of information students may be using. Bremner (2000) notes that over half of the students who had used other information were obtaining it via public libraries and a third of the students in the survey overall had used the public library to obtain materials, or as a quiet place to study. Only $15 \%$ of OU students had used academic libraries, partly because they were unaware that the majority of UK academic libraries can be used for reference purposes for free by students at other institutions. Many students reported difficulties in finding a library that had a good collection of relevant materials, and better access to other academic libraries would help in this regard, but according to Bremner, the OU Library realised that arranging borrowing rights for OU students at other institutions was problematic.

Suffice it to note here that in a discourse on the response of the UKOU to meeting the information needs of its distance learners, Bremner (2001) submits that it was decided early in the OU's history that it would be impractical to offer a library service to its (distance) students. According to Bremner, the course materials they were provided with would meet most of their information needs, and those needs that were not met could be provided through a public library, or by a nearby academic library. This practice, Bremner notes, continued to be the way student's information needs were met by the OU for twenty years until a number of changes in study methods and Government policy forced a rethink. Gradually the number of postgraduate courses increased, meaning that students needed to have a possibly different information seeking behaviour as they would carry out literature searches and produce dissertations. Alluding to a 1991 record of the Library Association, Bremner observes that by 1991 OU students were demanding access to their own library and protesting at the lack of access to academic libraries across the country. The OU Library's remit was changed in 1995 to reflect these changes.

Outside the Open University (OU), the information behaviour and practices of part-time and distance-learning students in higher education (HE) in the UK were also evaluated. Using questionnaire, telephone and face-toface interviews with a substantial sample of part-time and distance learners Rowland and Rubbert (2001) questioned whether the information-gathering practices of part-time and distance-learning students' best reflect the pedagogical concept of lifelong learning. Their results show that university libraries considered in their sample often did not cater for the specialised needs of part-time and distance learners, which leads to an increasing use of the Internet and employer resources as a substitute for traditional information channels. They observe that the students have major problems coping with the complexity of the WWW, and therefore make recommendations on how to improve existing information services in HE. Even though the use of electronic information was important, the study found that only $46 \%$ of the students had received an introduction to library and Internet resources.

While there is preponderance of literature on the information behaviour and/or environment of distance learners from advanced countries of the world, there seems to be dearth of studies on this subject in Africa. It is therefore palpable that the subject matter has not been given much attention it deserves in the continent that boasts the University of South Africa (UNISA) - one of the few mega distance teaching institutions in the world. The few studies done are worthy of note. Unfortunately, the first set of studies on the information behaviour of or how distance learners in Africa meet their information needs paint a gloomy picture. For instance it was Shillinglaw (1988) who first affirmed in UNISA that basic skills such as experience in alphabetization and familiarity with the concept of catalogues and the use of other bibliographic tools are not widely held. This observation was later confirmed in a paper on library services to distance learners of the University of South Africa by Behrens and Grobler (1997). The authors discourse on the information environment of distance learners of UNISA seems to revolve around the library. They observe that many UNISA students are unprepared and/or unable to use a library competently. Whilst blaming the manifestation of South African school system's deficiencies, the authors hint that the students from poor educational backgrounds often have little or no exposure to information services of any type before beginning their university studies. They affirm that such students, particularly at undergraduate level, register at UNISA lacking knowledge of how to use libraries and without a full understanding of the role of the library in the learning process. At postgraduate level, they argue that many UNISA students resume university studies after having been academically inactive for years. They regret that as postgraduate students tend to be older, factors in their environment such as family, work and community commitments may also be more demanding. They however stress that the UNISA libraries operate as conventional libraries for those who personally use the facilities; while the library acts as a document supply facility for students who rely 
on the postal and telecommunications services.

At the Open University in Tanzania (OUT), Mmari (1997) in a paper also regrettably notes that the distance learners of OUT were in the early years of the institution directed to meet their information needs through the stock of books and journals held by existing library systems in Tanzania. This stock according to Mmari was unfortunately limited in quantity and scope to support degree level programmes. Therefore the OUT had to approach some donors, unfortunately, some of the books received from these donors were in subjects that OUT does not offer. Mcharazo and Olden (1999) seem to follow the lead provided by Mmari when they did an interview survey on 54 students at the Open University of Tanzania (OUT) against the background that public libraries and even some academic libraries in Tanzania did not have the resources to support their coursework. Mcharazo and Olden observe that Internet access was poor and few students had access to personal computers. Students could only rely heavily on the study materials provided by the OUT. They counsel that all students would benefit if there was accessibility to additional information resources. Their recommendations include setting up an OUT radio station so that students could listen to modules of study. The authors also advocate for the university to also improve access to IT facilities. They observed that librarians might do more by providing students with acquisitions lists and perhaps indexing for articles in its collection. They advocate for the development of partnerships with the Tanzania Library Service (the public libraries) to provide some materials and study space for OUT students. Unfortunately, an arrangement with Tanzania (public) library service in the following year could only breed grievances on the part of the students. As noted by Mcharazo and Olden (2000) in another study, the students' complaint that the Tanzania Library Service had begun charging 3000 Tanzanian shillings a year (around three pounds sterling). Students found it difficult to afford this service "making the reading rooms quieter”!

In Kenya, Kamau (1997: p. 171) observes that distance learners at the University of Nairobi are theoretically entitled to the same library and information facilities as other students of the university. But in practice, students are encouraged to contribute some money used to buy books and are required to choose between two texts which would later be exchanged with another student. Thus, the information seeking behaviour of students of the institution revolves around students buying their own books and searching for whom to later exchange the books with. In 2004, Kavulya did what can be regarded as an update of Kamau's report in a case study of information services for distance learners of four universities in Kenya. Kavulya (2004: p. 15) examines what can be described as "information-meeting behaviour" of the distance teaching institutional libraries. Kavulya was of the view that although efforts have been made, there is room for improvement through adequate planning, financing and especially through collaboration between information personnel and those who design and implement such distance education programmes. It should however be stated that Kavulya's study is from the point of view of the university librarians of the universities involved in the study, as well as documentary sources.

At the University of Swaziland, Muswazi (2003) did a study on the quality and availability of library and information services and resources offered to distance learners in three campuses at Kwaluseni, Luyengo and Mbabane. The findings suggest that the respondents, mostly high school and unemployed residents of the Kingdom of Swaziland, were displeased with certain aspects of the distance service, particularly training in library use, information technology background, service quality, expenditures incurred, and availability of Internet resources. Public library services and support were also assessed. The areas of recommendation for improvements include increased budget, enhanced training opportunities, and improved policy and sharing among participating libraries. Boadi and Letsolo (2004) also did a study on information needs and information seeking behaviour of distance learners at the Institute of Extra-Mural Studies, Maseru in Lesotho. The study reveals that the distance learners live or work long distances from campus where they registered. They note that the (distance) learners therefore experience uneasy access to on-campus library and information sources and services. According to these researchers, living long distances from their institution, among others, has made distance learners depend on easily available sources of information such as colleagues, personal collections, co-workers and family members, which may not necessarily be the best sources of information to meet their needs. Knowing that information is an indispensable aid to learning they suggest that everything should be done to ensure that distance learners enjoy unimpeded access to needed information.

In Mabawonku's (2004) study carried out among some undergraduate distance learners in three Nigerian universities, it was revealed that the students used other libraries much more than the university libraries. However, the study shows that less than half of the respondents used their main university libraries regularly. The study further affirms that the students use some departmental libraries and other libraries outside the campus mainly 
for reading their personal books. It is noted that the distance learners hardly used reference and electronic resources. She also observes that majority of the students received no library use instructions. Mabawonku therefore regrets that a student could graduate without having used libraries. While Mabawonku notes that the distance learners she studied hardly used reference and electronic resources, she was silent on the extent to which the facilities, particularly electronic resources are available for the use of the learners.

In Botswana Oladokun (2002a) carried out a study of the Diploma in Primary Education (DPE) and Certificate in Adult Education (CAE) students of distance education of the University of Botswana and the role played by the University of Botswana Library. The results of the survey revealed that significant numbers of distance learners did not have access to a telephone (38\%), facsimile (78\%), a computer (89\%), email (92\%), or the Internet (97\%). While nine out of ten indicated a need for materials beyond course readings, almost half (48\%) had not used a library, a quarter used the University Library, and a quarter visited a public library. Among other things, Oladokun recommends that the university library should go into collaborative partnership with branches of the public library spread all over the country, establish more branches of its own library, and install computers with Internet access in the identified regional centres across the country.

\section{Information Sources/Channels Used by Distance Learners}

Information sources or channels are the means used to transfer information to a target population or audience. As earlier observed, information sources/channels constitute one of the major components of information environment. In order to have access to the information needed or required, there are a number of possible information channels, sources or resources that may be explored by distance learners. The reviews of some of the common and prominent sources are considered below.

\section{Mass-Media (Radio/Television Etc) as Information Sources}

For reasons of their easy accessibility and capability to reach a wide audience, mass-media, particularly radio and television, are known to be useful tools in open and distance learning. Indeed, these media are known to have been used by many distance teaching institutions to communicate with their students. They are used to achieve both teaching and non-teaching functions. Writing on the positive impact of the media in distance learning, Ivala (1999) states that the invention of television and video recording has the most profound influence on distance education. Ivala affirms that today, virtual classrooms are expanding in numbers due to common technologies like television and radio.

Radio and television broadcasts especially have the capacity to reach wider audience including people that are not targeted. Bates (2005) affirms that radio is accessible to more people than any other single technology. He believes that one problem of access is ensuring that students are able to listen when the programmes are actually broadcast. Bates (2005) supports his view by quoting a research on the accessibility of radio programme at the British Open University which found that there were always students who were unable to listen at any particular time, because they were either at work, traveling to or from work, or had other unavoidable commitments that prevent them from listening. There have been instances when mass-media, especially radio and television, are used for distance education purposes in different parts of the world such as America, China and UNISA in South Africa to mention a few. In China for instance, Xing-fu (2001: p. 3) records that the Central Bureau of Broadcasting on the Foundation of a National Radio and Television University System (CRTVU) "first transmitted courses via China Central Television's (CCTV) microwave network". He also notes that from 1979 to 1985, China's radio and TV higher education developed rapidly. Mass-media has been described as "a term used to denote, as a class, that section of the media specifically conceived and designed to reach a very large audience (typically at least as large as the whole population of a nation state” (Gupta, 2006: p. 2). Whilst using radio is audio, television is both audio and visual. As if to underscore the role of mass-media as viable sources of information, Sivaswaroop (2006), a deputy director at Indira Ghandi National Open University (IGNOU) in an online conference notes that in India, Radio and TV are widely spread. Quoting an estimate, he stresses that there are 111 million Radio sets and 112 million TV sets in the Country. He therefore hints that Radio and TV Broadcasts are widely used for education purpose. Sivaswaroop discloses the launching of a network of 40 FM Radio Stations named GYAN VANI; while GYAN DARSHAN, the cluster of Educational TV Channels encompassing School, Technical and Higher Education etc. is also available. He concludes that interactivity is built into these channels for effective educational purpose. 
Similarly, the use of mass-media like radio and television as educational tools in some African countries has been well documented. For instance, Jegede (2001) hints of the radio channel in Botswana that broadcasts 15-minute radio programmes on several subjects and that the Educational Broadcasting Division recently initiated a Distance Education Programme leading to a Primary Teachers' diploma with 600 young adults who have left school enrolling. Siabi-Mensah (2000) reports the use of radio in the non-formal education sector in Ghana. The Association for the Development of Education in Africa (ADEA, 2002) also notes the Mauritius College of the Air (MCA) use of radio, television, among others, to promote and enhance education. At the Open University Tanzania (OUT), Mcharazo and Olden (1999) in their study that involved 54 distance education students on how the information needs of these students will be adequately catered for recommended the setting up of an OUT radio station so that students could listen to modules of study.

In drawing dissimilarities between some broadcast modes, Kabonoki and Butale (2005) argue that the difference between educational instructions in broadcast mode and instructions in pre-recorded audio tape is that in broadcast mode, the learner has no control over the pace of delivery. In further illustrating this, the authors note that when the learner misses a content item due to a fast delivery pace or due to an interruption from the environment, the learner becomes helpless. In a noisy environment for instance, listening to broadcast can be disturbing. Kabonoki and Butale however conclude that it is not unusual to encounter sound interferences due to conditions of the atmosphere and other natural barriers.

\section{Colleagues as Information Sources}

Colleagues are an important information source to students. The Department of Communication of the University of Iowa (2006) argues in a publication that most of what we "know" is actually second-hand knowledge, information and insight that we obtain from others. The statement further hints that how we come to know anything is grasped in terms of symbols, and the meaning content of symbols is, in large part, determined by the form in which they are socially shared. This statement by the University of Iowa's Department of Communication studies seems to give credence to the fact that friends, peers or colleagues etc are sources of information.

In its attempt to offer a definition of colleague, The Oxford English Dictionary (1989: pp. 475-476) argues that colleague is "one who is associated with another (or others) in office, or special employment; strictly, said of those who stand in the same relationship... to the office which they jointly discharge”. It notes further that colleagues "join in alliance, unite and cooperate for a common end". For students, a colleague can also be a friend. In various conventional institutions of learning, students often work together, discuss together and share information with one another.

Even in non-conventional system, apart from chatting via the email and telephone, the occasional meetings of students often allow them to exchange ideas and information. As a matter of fact, students are never discouraged from having discussions and sharing ideas and information amongst themselves in the spirit of collegiality. According to the report on the Perceptions of Libraries and Information Resources by OCLC (2005) "friends" are identified as the principal source for information. The report also indicates that students use instant messaging to communicate with each other. Indeed, it is reported that this method (instant messaging) is the third most popular method of communication for students.

Writing on students communicating with each other in distance learning, Rowntree (1999) of the UK Open University observes that students not only write to their fellow students, "they have a freedom to say what they like, when they like and to an extent they like that is unparalleled even in face-to-face teaching". Rowntree affirms that in addition to public, computer conference messages to the group, they may also be sending private email messages to individuals, putting a new spin on the notion of a "hidden curriculum". He believes that the students may also refer their colleagues to the words of other "authorities" who may not be sanctioned by or even known to their teachers, perhaps even providing hot links to their Web pages.

In distance learning, it is known that students experience a lot of disadvantages unlike their conventional counterparts. The feeling of isolation is one typical trait known among most distance learners. A way of curtailing the disadvantages is to make use of colleagues and friends to bridge any existing gap that may arise. In a study on help-seeking strategies used by high-achieving and low-achieving distance education students at the Open University of Hong Kong, Taplin et al. (2001) find out that for personal problems, including self-motivation, test and examination anxiety, friends and fellow students (colleagues) were clearly the most frequently approached for help. In the high achievers' group $43 \%$ claimed they spend time with friends and colleagues. 
The use of colleagues as a source of information was underscored by some researchers in Africa as well. In their study on information needs and information seeking behaviour of distance learners in Lesotho, Boadi and Letsolo (2004) observe that the distance learners depend on easily available sources of information such as colleagues. The researchers however acknowledge that colleagues used as a source of information by distance learners at the Institute of Extra-Mural Studies, Maseru, Lesotho may not necessarily be the best sources of information to meet the learners' information needs. Kamau (1997: p. 171) also shares her experience on the exchange of books among fellow distance learners at the University of Nairobi, Kenya. She states that "in order to broaden their exposure, students are expected to exchange books among themselves". Similarly, two or three students could peer up and buy different books with a view to exchanging such amongst themselves later.

\section{Lecturers (Modules) as Information Sources}

Lecturers usually constitute a major source of information to students in academic environment. Keegan (1999: p. 50) observes the existence of "quasi-permanent separation of teacher and learner throughout the length of the learning process" in distance education. The separation distinguishes distance education from conventional face-to-face education. In order to bridge the separation, Keegan refers to the preparation of learning materials used by distance learners. Modules are probably better articulated by Holmberg (1990) when he notes that there is the use of pre-produced courses as the main basis of study. The modules therefore serve as the lecturers of distance learners and constitute a major source of information to them.

As a result of the distance between distance learners and their institutions, experts in the field advocate the need to promote active learning in the way the modules are produced as information source. For instance, Gachuhi and Matiru (1989) observe that the purpose of active learning is to help learners learn, by making them use the information encountered. They further note that active learning enables the writer and the learners build up a dialogue and also motivate learners to continue with the unit/module.

In his view on how to develop open learning materials, Rowntree (1990) believes that the module must generate activities. As such, Rowntree advises the course writer to among others, keep the objectives in mind as he/she writes, consider possible misconceptions learners may have and generate activities that will correct these; think of group exercise earlier successfully used in face to face teaching and re-create them; keep thinking about the learner whose material is being written and be creative. Rowntree also raised a number of questions which writers of the module need to bear in mind. These include: How much time are learners expected to spend on each activity? What do learners have to do to arrive at a response? How are they to record their response? Which of the learners' responses will merit a tutorial response? And how will feedback be ensured?

In their own submission on how to make the contents of the modules relevant, Adekanmbi and Somers-Vine (1996) suggest that there is the need to treat the building of the content within the framework of the context (national, local etc.) of the target group. These authors advocate that the development of the content is best done in small steps with the whole unit of instruction broken into parts, affirming that a unit of instruction should be coherent. In order to ensure cohesion of content, Adekanmbi and Somers-Vine suggest that the unit should be selfcontained, paragraph should present only one or two related ideas; sub-headings help learners to see that new ideas are being presented; bridges or links have to be built between sections or paragraphs and that main ideas have to be repeated at the end of a section.

Writing on their experience at the University of Botswana, Walwema and Thomas (2005: p. 48) share the views of authors like Moore (1988) and Keegan (1999). They note that in order to be able to design effective interactive lessons that will benefit distance learners, "writers must have a thorough understanding of basic instructional design strategies, relevant learning theories, typical profile of learners, how these differ from those in face-to-face setting and its implications; and how to develop instructional materials in a format suitable for independent study". The authors share their view with respect to the approach to take in designing modules. According to them, materials developed at the Distance Education Unit (DEU), University of Botswana, are interactive or self-contained. They confirm that dialogue is used incorporating numerous activities to engage the learner. Walwema and Thomas (2005: p. 48) note that the content of materials produced at DEU is "tailored precisely to the course at hand, uses examples and case studies to carry a local flavour and is complete in as far as the requirements of the course are concerned".

It is important to note that the modules which constitute a major package and source of information for distance learners have been categorized into two. According to Stephen and Unwin (1997), type A-the self-con- 
tained courses where students study from packaged materials (usually text-based but could include multi-media) and are not expected to read or consult sources beyond the supplied material. The students using Type B: described as the expandable package, study largely from packaged materials but wider reading would be recommended for certain sections of the course.

\section{World Wide Web (WWW) or the Internet as an Information Source}

Since its inception, the Internet or the WWW is known to be a vital and very useful source of information. According to W3C (2004), the World Wide Web (WWW, or simply Web) is an information space in which the items of interest, referred to as resources, are identified by global identifiers called Uniform Resource Identifiers (URI). Bates (2005: p. 8) also declares that the WWW is a particular component of the Internet, allowing digital materials to be created, stored, accessed and interacted with over the Internet. The World Wide Web (WWW) or simply put - the Web, is an extensive technology with a vast network of connected computers. Lehnert (1999: p. 12) calls it "the premier Internet application".

The Web or the Internet is a technological device that is commonly applied as a delivery medium in distance education. It is also greatly instrumental in the delivery of virtual library and information service to people in their homes, work etc. WWW-based learning activities can be considered as activities where information is sought and accessed across the network. This function makes the Web a very significant tool for the effective operation of open and distance education. Lehnert (1999: pp. 1-2) argues that, "until the early 1990s, the Internet was used by scientists and academics pursuing long-distance collaborations and scholarly research". It has already been established that, to a large extent, interpersonal communication and face-to-face interaction in learning group are somewhat eliminated in distance education. Keegan (1999: p. 8) quotes the German scholar, Peters describing these characteristics as "cultural imperatives for education in East and West". These traits of face-toface interpersonal communication as known in the conventional education are now being recreated in distance delivery mode with the virtual or electronic system, in which the Internet or WWW plays an active role. Previously the dominant means of communication highlighted by authors like Keegan (1996) and Holmberg (1990) were print, audio, video, telephone and broadcasting. The key features of the WWW, which makes its application indispensable to the providers of open and distance education and information, are well articulated by Oliver and Omari (1997). These include: information access, interactive learning and networked communication.

\section{Library as an Information Source}

There is preponderance of literature on the role of the library as an important information source in any academic setting. Libraries are regarded as one of the institutions that have a role in advancing literacy and education in the society. Akinpelu (1994) describes resources in the library as "the shrines where the saint is believed to be, and having built an ark to save learning from the deluge, deserve in propriety any new instrument or engine whereby learning should be advanced." Sharma (2002) on the other hand believes that libraries are a place where the written audio and visual communization plays the most important role in effective education. He affirms that the catalogues and systematized book houses are the silence zones where the goddess of wisdom has her full impact on the readership of a curious reader. Oladokun (2002b: p. 299) appreciates the library as "a necessary tool that should be taken into consideration and given a priority in open and distance education programme”. He maintains that "accessibility to library resources gives some impetus and enhancement to the quality of academic programmes run by any delivery mode-be it face-to-face or distance”. This view seems to have been corroborated by the Commonwealth of Learning (COL, 2003) when it states that libraries and librarians are as important to distance learning as they are to face-to-face education. COL emphasizes that librarians need to understand the mechanics and concepts of distance education to provide effective distance library service.

The significance of the library as an information source led the Association of College and Research Libraries (ACRL, 2004)—an arm of the American Library Association (ALA) to formulate "Guidelines for distance learning library services". The philosophy of the guidelines, among others, assume the precept that access to adequate library services and resources is essential for the attainment of superior academic skills in post-secondary education, regardless of where students, faculty, and programs are located. Comparing conventional students with distance learners, the "Guidelines" further state that members of the distance learning community are entitled to library services and resources equivalent to those provided for students and faculty in traditional campus settings. 
In the UK, the Society of College, National and University Libraries (SCONUL), the representative body for higher education and national libraries in the UK and Ireland, also creates a Task Force to address the library and information needs of distance learners registered in higher education institutions. SCONUL (2001) notes that higher education in general, and library and information services in particular, should be working towards the provision of flexible, "any time, any place" services for all their users. SCONUL states that the needs and expectations of the distance learning student can best be summed up in one word: access. The body believes the distance students will require timely access to information, space and help in a manner that matches their needs. This according to SCONUL will include for example, access to different sorts of study space, such as quiet study space, group study rooms and study areas equipped with PCs and possibly printers. It will embrace access to relevant information resources in a variety of formats, e.g. print, electronic, audio-visual, multi-media etc. Many other library associations such as the Canadian Librarian Association (CLA, 2000) and Indian Library Associations (2001) have written guidelines in support of distance education programmes.

\section{Library and Information Services for Distance Learners}

Closely related to the library as an information source are the services that are obtainable from this source. The trend in education worldwide has made various institutions of learning to diversify and accommodate distance education either as a single- or dual-mode system. This prompts the support of Mathews (1991) to the declaration of Patricia Cross in her observation that the trend is as clear as it is steady. Mathews observes that the college campus has burst explosively from its boundaries and affirms that decentralization of learning is a major trend of our times. He concludes by observing that more and more academic institutions are turning to offcampus programming. As more and more distance learning programmes are established, one great challenge confronting institutions of learning today is how to adequately provide effective and efficient library and information services to meet the needs of these learners who are geographically scattered and remote from the institution at which they are studying. The idea goes beyond the services rendered to staff and students in the libraries of the university campuses as it obtains in conventional system. In the conventional setting information needs are met usually within the library. Oladokun (2006: p. 103) defines the procedure "where the library only consults or is consulted within its own four walls in distance learning environment as an armchair system". He believes any library that still endeavours to indulge in the old stereotyped order will only succeed in becoming irrelevant as the emerging new educational system is redefined, reshaped and refocused.

Writing under the theme, overcoming the tyranny of distance, Meacham and Macpherson (1997: p. 183) roll out various library and information services which their institution, Charles Sturt University, Australia offered to distance learners of the institution. These include "information and reference service, use of other libraries, possibility of students' requests of services by phone, facsimile, post or e-mail”. Toll-free phones and after-hours answering facilities are also provided. Other services include reciprocal arrangements among three university libraries in Australia which offer distance education support and free photocopy of not more than one article from a single issue of a periodical. While the university pays forward mailing costs, students pay for return of items. Literature searches providing lists of citations are provided to enable students to access materials in the university or other libraries.

Massey University was known for its monopoly of distance education programmes for some 30 years in New Zealand. The university operates a dual-mode system. Bockett, Marsden and Pitchforth (1997: p. 102) report that "it was recognized from the outset that the distance learners would require additional reading materials in addition to the study guides provided". They assert that "the philosophy to give these students access to library service as nearly equivalent as possible to that enjoyed by internal students was put in place from scratch". According to Bockett, Marsden and Pitchforth (1997: p. 102) "the students could request for such services as the loan of a specific book, usually one referred to in their study guide". They note that books are delivered by courier, and issued for a period of three weeks; the students can ask for a photocopy of a specific journal article or single chapter of a book (the student is allowed to keep the article, but copyright regulations are observed; a photocopy of past examination papers for their course; and information/material on a particular subject. Bockett, Marsden and Pitchforth (1997) disclose that library staff will supply either a selection of books and/or articles, or a bibliography from which the student can select. Bockett, Marsden and Pitchforth maintain that the library endeavours to keep copies of all books recommended in the study guides. Inter library loans service was introduced as the number of students who are working on original research is growing, particularly at postgraduate 
level, many requests are received for books and journals articles which are not held.

At Monash University in Australia, Lim and Van Dyk (1997: p. 70) point out that "the university decided not to establish a traditional campus with print-based library and conventional teaching infrastructure”. According to Lim and Van Dyk (1997: p. 82), "the various components of virtual library service model established enables users to search the Library's online public access catalogue (OPAC), renew loans, place holds on items out on loan, display digitised images of the e-reserve collection, request inter-campus or inter-library loans, make requests directly to commercial document delivery services and access a range of online databases”. In addition, through the Monash Library Home Page, students can access a number of journals and Monash library guides and communicate with reference librarians electronically. They note that users could seek assistance to access the range of information resources provided, whilst the more sophisticated ones are able to bypass librarians to use the information resources directly.

At the distance teaching institution of Athabasca University, Canada, student can borrow materials from the library by mail, phone, fax, e-mail, or online. Students have 24-hour access to the Library Information Desk. When the Library is closed, requests for services can be left on voicemail or sent by fax or e-mail. Library staff acknowledges all requests within 24 hours. Materials are normally mailed to students' home addresses with an appropriate return card included for return of the materials to the AU Library (Athabasca University Library, 2007).

In Africa the experience of library and information provision does not fair any better than what obtains in West Indies. For instance Kamau (1997: p. 171) notes that at the University of Nairobi, Kenya "the external (distance) degree students are entitled to the same facilities as other students". She however regrets that "this is only possible when the students are actually on campus during residential sessions". She mentions a number of library facilities that the students could approach including the Kenya National Library Service, College libraries and British Council libraries. She adds that the Kenya National Library Service is provided with a list of recommended reference books. Another researcher, Kavulya (2004) confirms Kamau's report in his findings that the Faculty of Education of the University of Nairobi used part of the fees paid by the external students to buy essential books and distributed them to students. This procedure was soon discontinued as it proved unsustainable. The students are therefore encouraged to either buy their own books, borrow from public libraries, public university libraries or non-governmental institutions. At Kenyatta University, Kavulya's study established that students had to visit the university library to access and borrow reading materials or make use of other relevant libraries in their locality. While some depressing picture is observed in the two institutions mentioned, a more encouraging scenario was found in the service to distance learners of African Virtual University (AVU). Kavulya (2004: p. 22) confirms that "AVU library has created a digital library consisting of e-journals, e-books and online archives to facilitate access to worldwide resources by students". Though the study confirms that all students obtain user identification, whether they are all able to access the facilities from their various locations as and when required is another matter.

After the failure of the decision of Open University in Tanzania (OUT) not to provide direct library services to its students as reported by Mmari (1997), Msuya and Maro (2002) observe that OUT main library provides services to staff and students residing in Dar es Salam-the capital of Tanzania. Some books and other reading materials are placed at branches of the Tanzania Library Services (public library) for students living in those areas. The university also established Information units in all Regional Centres where some reading materials and course manuals are kept for students. Msuya and Maro however affirm that OUT library does not have enough materials to meet the needs of the academic staff and students based in Dar es Salam. In order to solve the problem, OUT students are encouraged to register with the University of Dar es Salam.

In Nigeria, a pathetic case of absence or near-absence of library and information services to distance learners was presented in a research carried out by Mabawonku (2004) on library use by distance learners in three Nigerian Universities. The distance learners of the University of Ibadan, according to Mabawonku (2004: p. 159), were given library cards on registration. Unfortunately, she notes that "the cards only allowed them to sit and use the resources in the library". They were not allowed to borrow materials out of the library, neither was any inter library loans facility extended to them. At the University of Ilorin, Mabawonku hints that the students were not allowed to use the library and they could not enjoy loans facilities. Only the University of Lagos distance learners were allowed book loans at the main campus library. Some arrangements of inter-library loans, Mabawonku discloses, are also made for them.

In South Africa is located one of the world's mega distance teaching institutions, University of South Africa. 
According to Hartzer et al. (1998), the students are encouraged to buy their own prescribed books, while the library supplies copies of recommended materials that are usually required to be consulted at specific stages during the course. They point out that the library has built up a large collection of books, known as the Study Collection, to assist in meeting this requirement. In order to meet the information needs of its numerous students in South Africa, UNISA maintains some branch libraries in regional offices apart from the main library. "The university also maintains relationship with some municipal libraries where limited book collections are kept. Students access the collections either through a personal visit to any of the libraries or have the library materials posted to them. Using the latest information technology, the entire collection is accessed through an opacsystem with terminals located not only in the main library but also throughout the main campus and branch libraries" (Behrens \& Grobler, 1997: p. 83). It thus looks that UNISA caters for its students living within South Africa to some extent.

The University of Botswana (UB) operates a dual mode system. Oladokun (2002: p. 298) observes that "the library and information service being developed for distance learners follows the model of UNISA. Operating under the Customers and Extension service unit, the UB Library maintains a small collection of some recommended materials in some regional centres where the students meet for occasional residential sessions”. The entire library collection is also accessible through an opac system. Whilst books, on request, can be posted to the students in their various locations, it is required of them (the learners) to pay for the return postage. Further, electronic databases provide references to periodical articles in a wide variety of subjects. It thus means that students with access to the Internet can access some of these databases and indexes, to which the University of Botswana Library subscribes. Such databases include EbscoHost, Emerald and SA ePublications. Students are also taught information skills in the general education course (GEC) 121 and 122 to search electronic resources (UBL, 2004).

\section{Conclusion}

For purposes of this review, information environment is structured into information needs, information sources and information seeking behaviour of distance learners. Under the umbrella of information environment of distance learners, the review was extended to examining the various studies or researches that have been carried out on information needs and information (seeking) behaviour of distance learners. Further, the channels and, or sources of information used by distance learners to meet their information needs were given consideration in the course of carrying out the review of literature. The information channels or sources specifically reviewed include mass-media (Radio/Television), colleagues, lecturers (modules), WWW or the Internet and the library.

\section{References}

ACRL (2004). Guidelines for Distance Learning Library Services. http://www.ala.org/ala/acrl/acrlstandards/guidelinesdistancelearning.htm

ADEA (2002). Open and Distance Learning in Sub-Saharan Africa: A Literature Survey on Policy and Practice (ADEA Working Group on Distance Education and Open Learning-February 2002) (pp. 35-36).

Adekanmbi, G., \& Somers-Vine, T. (1996). Teaching through Distance Education (pp. 1-28). Paper Presented at the Distance Education Orientation Workshop Organized by the DEU, Tlokweng: Centre for Continuing Education, University of Botswana.

Akinpelu, J. A. (1994). Education for Special Groups. In O. O. Akinkugbe (Ed.), Nigeria and Education: The Challenges Ahead (pp. 158-190). Ibadan: Spectrum Books Ltd.

Athabasca University Library (2007). Circulation Services. http://library.athabascau.ca/lib-services/libserv.php

Bates, A. W. (2005). Technology, E-Learning and Distance Education. London: Routledge.

Behrens, S. J., \& Grobler, L. M. (1997). The University of South Africa’s Library Services to Distance Learners. In E. F. Watson, \& N. Jagannathan (Eds.), Library Services in the Commonwealth: A Reader. Vancouver: The Commonwealth of Learning.

Boadi, B. Y., \& Letsolo, P. (2004). Information Needs and Information Seeking Behaviour of Distance Learners at the Institute of Extra-Mural Studies in Lesotho. Information Development, 20, 189-199. http://idv.sagepub.com/cgi/content/abstract/20/3/189

Bockett, C., Marsden, L., \& Pitchforth, J. (1997). Library Services to Distance Learners at Massey University: Some Man- 
agement Issues. In E. F. Watson, \& N. Jagannathan (Eds.) Library Services in the Commonwealth: A Reader (pp. 101-108). Vancouver: The Commonwealth of Learning.

Bremner, A. (2000). Open University Students and Libraries Project 1999. Library and Information Research News, 24, 26-38.

Bremner, A. (2001). Meeting the Information Needs of Distance Learners-The Open University’s Response. Vine, 122, 54-58. http://library.open.ac.uk/aboutus/students/reports/PUBLICATION_VINE_Info_Needs_AB-2001.01.doc

Canadian Library Association (CLA) (2000). Guidelines for Library Support of Distance and Distributed Learning in Canada. http://www.cla.ca/about/distance.htm

Commonwealth of Learning (COL) (2003). Developing Library and Information Services for Distance Education. http://www.col.org/colweb/site/pid/3131

Gachuhi, D., \& Matiru, B. (1989). Handbook for Designing and Writing Distance Education Materials. Bonn: Deutsche Stiftungfr Internationale Entwicklung.

Gupta, O. M. (2006). Encyclopaedia of Journalism and Mass Communication: Mass Media. India: Isah Books.

Hartzer, S. et al. (1998). Web Information Services at the University of South Africa Library: A Work in Progress-Library Trends. http://findarticles.com/p/articles/mi m1387/is 1 47/ai 53523840

Holmberg, B. (1990). Foundations of Distance Education. London: Kogan Page.

Indian Library Association (2001). Guidelines for Library Services to Distance Learners. http://uviclib.uvic.ca/dls/LSDL Guidelines.pdf

Ivala, E. (1999). The Internet and Distance Education. A Paper Presented at the 1st National NADEOSA Conference.

Jagannathan, N. (1998). Libraries in Distance Teaching University. In: M. K. Jain et al. (Eds.), 50 Years Library and Information Services in India. Delhi: Shipra Publications.

Jegede, O. (2001). The Use of Distance Education Methodologies for Primary Teacher Education in Nigeria. In: Primary Teacher Education: The Use of Distance Education Methodologies for Primary Teacher Education in Nigeria. Vancouver: Commonwealth of Learning.

Kabonoki, K., \& Butale, C. (2005). Media in Open and Distance Education. In J. Walwema (Ed.), Tutors Training Manual. Gaborone: CCE, Distance Education Unit, University of Botswana.

Kamau, J. W. (1997). Providing Support Services for the External B.Ed. Distance Learners Programme at the University of Nairobi. In E. F. Watson, \& N. Jagannathan (Eds.), Library Services in the Commonwealth: A Reader (pp. 165-174). Vancouver: The Commonwealth of Learning.

Kascus, M., \& Aguilar, W. (1988). Providing Library Support to Off-Campus Programmes. College and Research Libraries, 49, 29-37.

Kavulya, J. M. (2004). Challenges in the Provision of Library Services for Distance Education: A Case Study of Selected Universities in Kenya. African Journal of Library, Archives and Information Science, 14, 15-28.

Keegan, D. (1996). Foundations of Distance Education. London: Routledge.

Keegan, D. (1999). Foundations of Distance Education. London: Routledge.

Kelley, K. B., \& Orr, G. J. (2003). Trends in Distant Student Use of Electronic Resources: A Survey. College \& Research Libraries, 64, 176-191.

Lehnert, W. G. (1999). Light on the Internet: Essentials of the Internet and the World Wide Web. Boston, MA: Addison Wesley Longman, 1-12.

Lim, E., \& Van Dyk, M. T. (1997). Library Support Models for Distance Education: The Australian Experience. In C. A. Snyder, \& J. W. Fox (Eds.), Libraries and Other Academic Support Services for Distance Learning (pp. 70-82). Greenwich, CT: Jai Press.

Liu, Z., \& Zheng, Y. Y. (2004). Factors Influencing Distance-Education Graduate Students' Use of Information Sources: A User Study. Journal of Academic Librarianship, 30, 24-35. http://dx.doi.org/10.1016/j.jal.2003.11.005

Mabawonku, I. (2004). Library Use in Distance Learning: A Survey of Undergraduates in Three Nigerian Universities. African Journal of Library, Archives and Information Science, 14, 151-165.

Mathews, A. J. (1991). Accepting the Challenge: Providing Quality Library Services for Distance Education Programs. In B. M. Lessin (Ed.), Off-Campus Library Services: Selected Readings from Central Michigan University's Off-Campus Library Services Conferences. Metuchen, NJ: The Scarecrow Press.

Mcharazo, A. A. S., \& Olden, A. (1999). Investigating the Learning Resource Requirements of Students at the Open University of Tanzania: Research Methods. Journal of Librarianship and Information Science, 31, 101-109.

Mcharazo, A. A. S., \& Olden, A. (2000). Fulfilling the Learning Resource Requirements of Students at the Open University of Tanzania. Journal of Librarianship and Information Science, 32, 204-214. 
McLean, E., \& Dew, S. H. (2004). Assessing the Library Needs and Preferences of Off-Campus Students: Surveying Distance Education Students, from Midwest to the West Indies. In P. B. Mahoney (Ed.), The Eleventh Off-Campus Library Services Conference Proceedings. Philadelphia, PA: The Haworth Press.

Meacham, D., \& Macpherson, M. H. (1997). Overcoming the Tyranny of Distance. In E. F. Watson, \& N. Jagannathan (Eds.), Library Services in the Commonwealth: A Reader (pp. 183-192). Vancouver: The Commonwealth of Learning.

Mmari, G. R. V. (1997). Library Services for the Open University of Tanzania: Experiences of the First Year. In E. F. Watson, \& N. Jagannathan (Eds.), Library Services in the Commonwealth: A Reader (pp. 193-198). Vancouver: The Commonwealth of Learning.

Moore, M. (1988). On a Theory of Independent Study. In D. Sewart, D. Keegan, \& B. Holmberg (Eds.), Distance Education: International Perspectives. London: Routledge.

Moyo, L. M., \& Ellysa, S. C. (2003). Meeting the Needs of Remote Library Users. Library Management, 24, 281-290. http://dx.doi.org/10.1108/01435120310485995

Msuya, J., \& Maro, F. (2002). The Provision of Library and Information Services to Distance Learners: The Open University of Tanzania (OUT). Libri, 52, 183-191. http://dx.doi.org/10.1515/LIBR.2002.183

Muswazi, P. (2003). Distance Education Library Services in Swaziland. Information Development, 19, $214-224$. http://dx.doi.org/10.1177/0266666903193011

OCLC (Online Computer Library Center) (2005). Perceptions of Libraries and Information Resources. http://www.oclc.org/reports/pdfs/Percept_all.pdf

Oladokun, O. S. (2000). New Technology, New Clientele: Distance Still Remains in Library Service. Paper Presented at Distance Education: An Open Question? An International Conference Sponsored by the University of South Australia in conjunction with the International Council for Open and Distance Education (ICDE). The University of South Australia, Adelaide, 11-13 September 2000. http://www.unisanet.unisa.edu.au/cccc/papers/refereed/paper31/Paper31-1.htm

Oladokun, O. S. (2002a). Distance Education and the Role of the Library: A Case Study at the University of Botswana. MIS Dissertation, Pretoria: University of Pretoria.

Oladokun, O. S. (2002b). The Practice of Distance Librarianship in Africa. Library Review, 51, 293-300. http://dx.doi.org/10.1108/00242530210434037

Oladokun, O. S. (2006). The Networked World of Lifelong Learning and the Challenging Role of the Library. Information Development, 22, 102-109.

Oliver, R., \& Omari, A. (1997). Using the WWW to Support Distance Education and Open Learning. In J. Osborne, D. Roberts, \& J. Walker (Eds.), Open, Flexible and Distance Learning: Education and Training in the 21st Century. 13th Biennial Forum of Open and Distance Learning Association of Australia, 29 September-3 October 1997. Launceston: University of Tasmania.

Rowland, F., \& Rubbert, I. (2001). An Evaluation of the Information Needs and Practices of Part-Time and DistanceLearning Students in the Context of Educational and Social Change through Lifelong Learning. Journal of Documentation, 57, 741-762. http://cat.inist.fr/?aModele=afficheN\&cpsidt=14129576 http://dx.doi.org/10.1108/EUM0000000007105

Rowntree, D. (1990). Teaching through Self-Instruction: How to Develop Open Learning Materials. New York: Kogan Page.

Rowntree, D. (1999). A New Way with Words in Distance Education. http://www-iet.open.ac.uk/pp/D.G.F.Rowntree/words_in_de.htm

SCONUL (2001). Access for Distance Learners: Report of the SCONUL Task Force. www.sconul.ac.uk/pubs stats/pubs/distancelearners report.doc

Sharifabadi, S. R. (1992). Information Gathering Behaviour of Students Studying in Distance Education and Off-Campus Programs at University Level. http://www.alzahra.ac.ir/REZAEI/off-camp.htm

Sharma, P. L. (2002). Role of Library Services in Distance Learning. http://www.ignou.ac.in/aaou-pre/Sharma,PL.htm

Shillinglaw, N. (1988). Supplying Library Materials to Undergraduate Students of a Distance Teaching University. Progressio, 10, 17-26.

Siabi-Mensah, K. (2000). Ghana: The Use of Radio in the National Literacy and Functional Skills project in the Volta and Northern Regions. In R. Siaciwena (Ed.), Case Studies of Non-Foraml Education by Distance and Open Learning. Vancouver: Commonwealth of Learning/International Extension College.

Singh, B. K. (2002). Library Services to Distance Learners: A Study of Kota Open University. Paper Presented at the AAOU Pre-Conference Seminar on Outreach Library Services for Distance Learners.

http://www.ignou.ac.in/aaou-pre/BK\%20Singh.htm

Sivaswaroop, P. (2006). PCF4 Collaboration: Appropriate Technologies. Contribution Made by Pathanenisivaswaroop [psivaswaroop@yahoo.com] during an Online Conference Organized by the Commonwealth of Learning.

Stephens, K., \& Unwin, L. (1997). The Heart of the Matter: Libraries, Distance Education and Independent Thinking. The 
Journal of Library Services for Distance Education, 1, August 1997.

http://www.westga.edu/ library/jlsde/vol1/1/KStephens_LUnwin.html

Sutherland, J. (2000). Distance Education: Library Use among Adult Distance Learners: Its Implications for Local Public and Academic Libraries. A Capstone Project. MLIS Thesis, University of Denver. http://www.du.edu/lisa/capstone/Capstone Projects/j sutherland.pdf

Taplin, M. et al. (2001). Help-Seeking Strategies Used by High-Achieving and Low-Achieving Distance Education Students. Journal of Distance Education/Revue de l'enseignement à distance. http://cade.athabascau.ca/vol16.1/taplin.html

The Oxford English Dictionary (1989). Colleague in The Oxford English Dictionary (2nd ed., Vol. III). Oxford: Clarendon Press.

University of Iowa. (2006). Bridging the Digital Divide. Fyi, 43. http://www.uiowa.edu/ fyi/issues/issues2006_v43/11062006/feature1.html

University of Iowa. (2006). The eGranary Digital Library: How It Works.

http://www.widernet.org/digitalLibrary/HowItWorks.htm

W3C (2004). W3C Recommendations. In I. Jacob (Ed.), Architecture of the World Wide Web (Vol. 1). http://www.w3.org/TR/webarch/\#acks

Walwema, J., \& Thomas, P. Y. (2005). Tutoring with DEU Learning Materials. In Tutors Training Manuals (p. 48). Gaborone: Distance Education Unit-CCE, University of Botswana.

Xingfù, D. (2001). China. In O. Jegede, \& G. Shive (Eds.), Open and Distance Education in Asia Pacific Region. Hong Kong: Open University of Hong Kong Press. 